\title{
LEAN STARTUPS WITH INDUSTRY 4.0 TECHNOLOGIES: OVERCOMING THE CHALLENGES OF YOUTH ENTREPRENEURSHIP IN SERBIA
}

UDC: 005.96(497.11)

005(497.11)

Original Scientific Paper

\section{Mihalj BAKATOR ${ }^{1}$, Dejan ĐORĐEVIĆ ${ }^{1}$, Dragan ĆOĆKALO ${ }^{1}$, Milan NIKOLIĆ ${ }^{1}$, Miloš VORKAPIĆ ${ }^{2}$}

\author{
${ }^{1}$ University of Novi Sad, Technical Faculty "Mihajlo Pupin” in Zrenjanin, 23000 Zrenjanin, Đure Đakovića bb, \\ Republic of Serbia \\ E-mail: mihalj.bakator@uns.ac.rs \\ ${ }^{2}$ University of Belgrade, Institute of Chemistry, Technology and Metallurgy - Centre for Microelectronic \\ Technology and Mono-crystals, 11000 Belgrade, Njegoševa 12, Republic of Serbia
}

Paper received: 20.09.2018.; Paper accepted: 28.10.2018.

\begin{abstract}
Youth entrepreneurship is important for reducing youth unemployment rates and it overall contributes to economic growth. The main idea of this research is to determine the barriers and challenges that young entrepreneurs face in Serbia. The paper analyzes literature in this domain, and compares the status of youth entrepreneurship and entrepreneurship overall between Serbia, the EU and the US. Furthermore, a theoretical model is developed that includes the application of Industry 4.0 (I4.0) technologies and lean startup approach. The results indicate that taxation regulation and the lack of financial support for new startups are the main barriers that the young face in Serbia. In addition, the lack of adequate entrepreneurial education creates difficulties, and demotivates potential entrepreneurs. Therefore, it is necessary to introduce or modify existing regulatory laws and introduce effective financial support for new enterprises.
\end{abstract}

Keywords: Youth entrepreneurship, Industry 4.0, Lean startups, Serbia.

\section{INTRODUCTION}

Small and medium-sized enterprises (SMEs) are an incredible driving force of economic growth and creator of new jobs in transition economies and in developed economies as well (Bollingtoft, \& Ulhoi, 2005). In the United States entrepreneurship is a key component of economic development. Every year, the dynamicity of the entrepreneurial sector is ever more intensified, while Europe lacks behind when it comes to entrepreneurship and this is mainly due to lack of young entrepreneurs (Wilson, 2008). The situation is even worse in the Republic of Serbia, where there is little to no stimulation, encouragement nor motivation of youth to start their own business (Djordjevic, Cockalo, Sajfert, Bogetic, \& Klarin, 2011). Now, according to the Doing Business ranking report, Serbia holds a solid $32^{\text {nd }}$ place from 190 countries in the "Starting a new business" category in 2018,
(World Bank, 2017). However, in Serbia youth unemployment is recorded to be far greater than general unemployment (Milanovic, \& Angelovski, 2013). One of the ways to increase the volume of youth entrepreneurial endeavors is through education that focuses on developing entrepreneurial culture and skills (Wach, 2014). Early entrepreneurial education helps students to base their careers on solid grounds which are complementary and compatible with global entrepreneurial trends (Otović, Demirović, Košić, \& Vujko, 2017). As mentioned before, SMEs contribute to lowering inequality of incomes, positively affect resource allocation, and reduction of economic differences between rural and urban areas (Aničić, Aničić, \& Vasić, 2017). Certainly, SMEs are key to youth unemployment reduction. The question is: How can young entrepreneurs start their business with low costs and in the most effective way in order to reduce financial risk, and 
overall risk of failure? The answer to this question lies in the "Lean startup" approach and in the use of Industry 4.0 (I4.0) technologies. Lean startups can be presented as a business model where products and services are tested, modified through the feedback of customers. The goal is to reduce initial costs through experiments that help determine a sustainable business model (Bortolini, Nogueira, Danilevicz, \& Ghezzi, 2018). Industry 4.0 is a term used to describe the fourth industrial revolution and its main goal includes higher levels of productivity and operational efficiency. Industry 4.0 includes technologies such as Enterprise Resource Planning (ERP), Radio Frequency Identification (RFID), social product development, cloud based manufacturing and Internet of Things (Lu, 2017).

In this paper the lean startup approach and some of the technologies in I4.0 for youth entrepreneurship improvement is addressed. The research includes literature analysis and data analysis in this domain. Additionally, a theoretical model is developed and suggestions are made for regulations and procedures that should be conducted in order to create a friendly economic environment for young entrepreneurs. The main idea of this research is to provide substantial answers to the following research questions:

1. What are the main challenges of youth entrepreneurship in Serbia and how does it compare to developed countries in the EU and US?

2. What approach can be taken for youth entrepreneurship improvement?

Furthermore, besides the Introduction and Conclusion sections, this present paper consists of four additional ones. The first section discusses the importance of entrepreneurship for youth employment and overall economic prosperity. The second section includes a comparative analysis of youth entrepreneurship and entrepreneurship in Serbia, in the EU and US. Further, the third section presents a model for youth entrepreneurship based on lean startup and I4.0 technologies. Discussion about the findings and research questions is given in the fourth section. In addition, potential solutions for youth entrepreneurship improvement are suggested. Finally, conclusions are drawn, the limitations of the research are addressed, and guidelines for future research are recommended.

\section{THE IMPORTANCE OF ENTREPRENEURS AND ENTREPRENEURSHIP FOR ECONOMIC PROSPERITY}

Entrepreneurship can be viewed as a set of actions of individuals or groups that focus on creating new economic opportunities outside of established organizations (Carree, \& Thurik, 2010). However, in the same research it was argued that entrepreneurship is connected to individual or small team ideas. Therefore, linking the actions of individuals to macro-economic performance indicators or overall economic growth is questionable. In contrast, if overall increase of entrepreneurship, especially among the young, has shown a decrease of youth unemployment, that itself is sufficient for further discussion about the impact of entrepreneurship on economic growth. Furthermore, the research of Boettke and Coyne (2015) discussed the possibility that entrepreneurship is not the cause but the consequence/result of economic development and growth. In addition, the study clearly depicted the difference between Schumpeter's view on entrepreneurship who views entrepreneurs as innovators, and Kirzner's view, who sees entrepreneurs as someone who seeks opportunities that opened up as a result of errors of other market participants. This would mean that entrepreneurs don't actively create opportunities but rather challenge existing ones through various forms of experimentations with the market.

Furthermore, other studies argued that entrepreneurs seek opportunities in functions that have low returns and turn them into functions that have high returns. This way, resources are re-allocated in a matter that it increases their efficiency. The opposite of this is a rigid economy where various resources are underused (Acs, \& Storey, 2004). In other words, entrepreneurs create dynamic market environments where resources gain "velocity", thus creating value. The underlying functions that govern these changes on the markets are influenced by the actions of entrepreneurs. In a later study conducted by Acs, Desai, and Hessels (2008), it was noted that entrepreneurship has various effects on economic development and that it depends on the type of markets and existing economic state of the country. Opportunistic entrepreneurship has shown to positively affect economic development, while entrepreneurship out of necessity or necessity entrepreneurship doesn't have a positive effect. Certainly, the various 
dynamic factors of a country affect the majority of entrepreneurial activity. For example national culture, the education system and whether the country is developed or in transition, can factor in how entrepreneurship is viewed and regarded. In post-communist, transitional countries, there could be difficulties for accepting entrepreneurship as a valid and sustainable source of employment and income.

Next, entrepreneurship is considered to be the source of innovations and a driving force of markets. The innovation for entrepreneurs often comes from the places they live. The cities or rural areas function as incubators for creativity. These observations where noted in the research of Lee, Florida, and Acs (2004). Complementary to their findings Minniti and Lévesque (2008) noted that entrepreneurship creates diversity of knowledge and distributes that knowledge between individuals. It is also mentioned that entrepreneurs have a significant role in the economy as they increase employment rates, contribute to productivity, and utilize various innovations that may result in with spillovers to regional markets. Further, entrepreneurship can offer a positive impact on economic development in developing countries through overall growth of the economy, changes within the structure of markets, and potential relief from poverty and resource scarcity among the population (Naudé, 2010). In the same study it was discussed that there are several obstacles that may lead to failure when it comes to entrepreneurship. These may include governmental policies and cultural drawbacks if there is no adequate education regarding entrepreneurship. To overcome these issues, developing countries should invest in entrepreneurial education and to clearly define the large set of policies that govern entrepreneurial behavior in a country.

When it comes to SMEs, entrepreneurial behavior is characterized by three main components. These are risk taking, innovativeness and pro-activeness (Wiklund, \& Shepherd, 2003). Sobel, Clark, and Lee, (2007) pointed out that the difference in economic growth through various geographic areas are the result of different variations and intensity of entrepreneurial behavior. Interestingly, innovation can have a positive impact on economic growth indirectly through entrepreneurship (Audretsch, Bönte, \& Keilbach, 2008). Finally, Van Stel, Carree, and Thurik (2005) note that entrepreneurs and entrepreneurial activity can positively affect economic growth but the amount of positive impact depends on other economic factors as well, such as income per capita. In addition, it was also discussed that entrepreneurship has different influences in different countries depending on their economic development.

Based on the above mentioned studies, it is evident that there is a positive effect of entrepreneurship on economic growth as it contributes to lowering unemployment rates, reducing poverty, increasing overall value of various markets and enhancing innovativeness and productivity. However, there are other factors that may influence the success of entrepreneurial activities such as government policies, regulations and market maturity. In the next section a comparative analysis is conducted comparing performance metrics of youth entrepreneurship and entrepreneurship overall in Serbia, EU and the US. The section investigates some of the key elements that define entrepreneurship as a whole. The data for the section is obtained from various sources and it is analyzed in accordance with the main goal of this paper.

\section{COMPARATIVE ANALYSIS OF YOUTH ENTREPRENEURSHIP IN SERBIA, EU AND THE US}

In this section youth entrepreneurship is analyzed and compared between Serbia, the EU and the US. The main focus is on entrepreneurship education and government policies that severely affect new entrepreneurs. There are lots of factors that define entrepreneurship potential in a country. A large number of studies show that education is a significant factor when it comes to youth entrepreneurship (Karanassios, Pazarskis, Mitsopoulos, \& Christodoulou, 2006; Rodrigues, Raposo, Ferreira, \& Paco, 2010; Shinnar, Pruett, \& Toney, 2009). Certainly, an effective educational system that nourishes entrepreneurship is important for economic development. According to the research conducted by Somer et al. (2018) the majority of students in Serbia feel that they are totally uninformed or little bit informed about entrepreneurship as a viable career. Additionally, students see the lack of perspective and starting capital as main barriers for entrepreneurship. Regulatory laws are also moderate to big issues for starting a business. Figure 1 depicts two charts which show how well informed are students about 
entrepreneurship and what they perceive as barriers for starting business in Serbia.
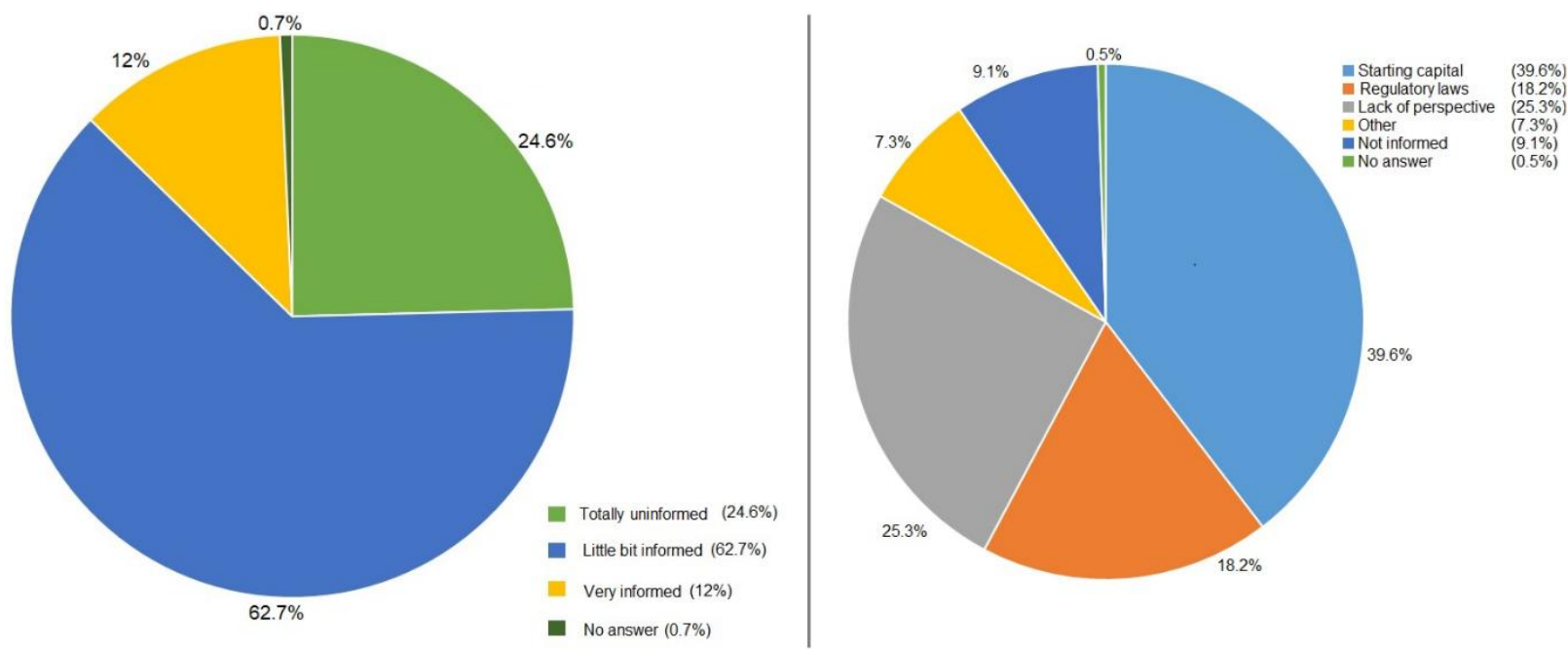

Figure 1: Students opinions on how well they are informed about entrepreneurship in Serbia and what are the barriers for starting business

Source: Somer et al., 2018

Now, the Global Entrepreneurship Monitor Report for 2018 (GEM, 2018) investigated several economies including countries from the EU and the USA as a whole. In this report there are large sets of data. However, for this present paper only some of the data are presented. Table 1 depicts the extracted data from the GEM 2018 report.

Table 1: Entrepreneurship parameter measurement data for the EU and the US

\begin{tabular}{|c|c|c|}
\hline Measured parameter & EU & US \\
\hline Framework conditions & $4.5^{*}$ & $5.2 *$ \\
\hline Entrepreneurial finance & $4.48^{*}$ & $5.2 *$ \\
\hline $\begin{array}{l}\text { Government policies, } \\
\text { support and relevance }\end{array}$ & $4.21 *$ & $5.2 *$ \\
\hline $\begin{array}{l}\text { Government taxes and } \\
\text { bureaucracy }\end{array}$ & $3.78 *$ & $5.0^{*}$ \\
\hline $\begin{array}{l}\text { Government } \\
\text { entrepreneurship programs }\end{array}$ & $4.47 *$ & $5.4^{*}$ \\
\hline $\begin{array}{l}\text { Entrepreneurial education } \\
\text { school age }\end{array}$ & $3.27 *$ & $4 *$ \\
\hline Education post school age & $4.68 *$ & $5.2 *$ \\
\hline Motivation among students & $75.40 \%$ & $82.60 \%$ \\
\hline
\end{tabular}

Source: GEM, 2018

Based on the data presented in Table 1, it can be seen that the US has higher average scores for every measured parameter compared to the EU.
The values for both economic regions indicate that there is medium to upper-medium sufficiency when it comes to framework, finances, government support and taxation and post-school education. In comparison, in Serbia $73 \%$ of students stated that the higher education system in Serbia is not insync with the demands of the job-market (Somer et al., 2018). The Serbian government has difficulties to keep up with the rising number of young educated people (Bobić, 2017). It was noticed that Serbia wasn't included into the GEM 2018 report, nor in the previous seven consecutive years. Serbia participated in this significant report only for three years from 2007 to 2009 (Bobić, 2017). Therefore, there is lack of data that would allow a sleek comparison with other countries/economies. Next, compared to Serbia where the government hasn't fully acknowledged the importance of entrepreneurship, in the US the White House has pointed out that entrepreneurship is the source of innovation and economic development, thus supporting innovation-based entrepreneurship as a necessity (Rae, \& Melton, 2017). The impact of education on entrepreneurship can be seen in the findings of Saraiva and Gabriel (2016). Students were asked how they perceived the role of schools in the decision to become an entrepreneur. Figure 2 depicts the results for some of the European Union countries. 


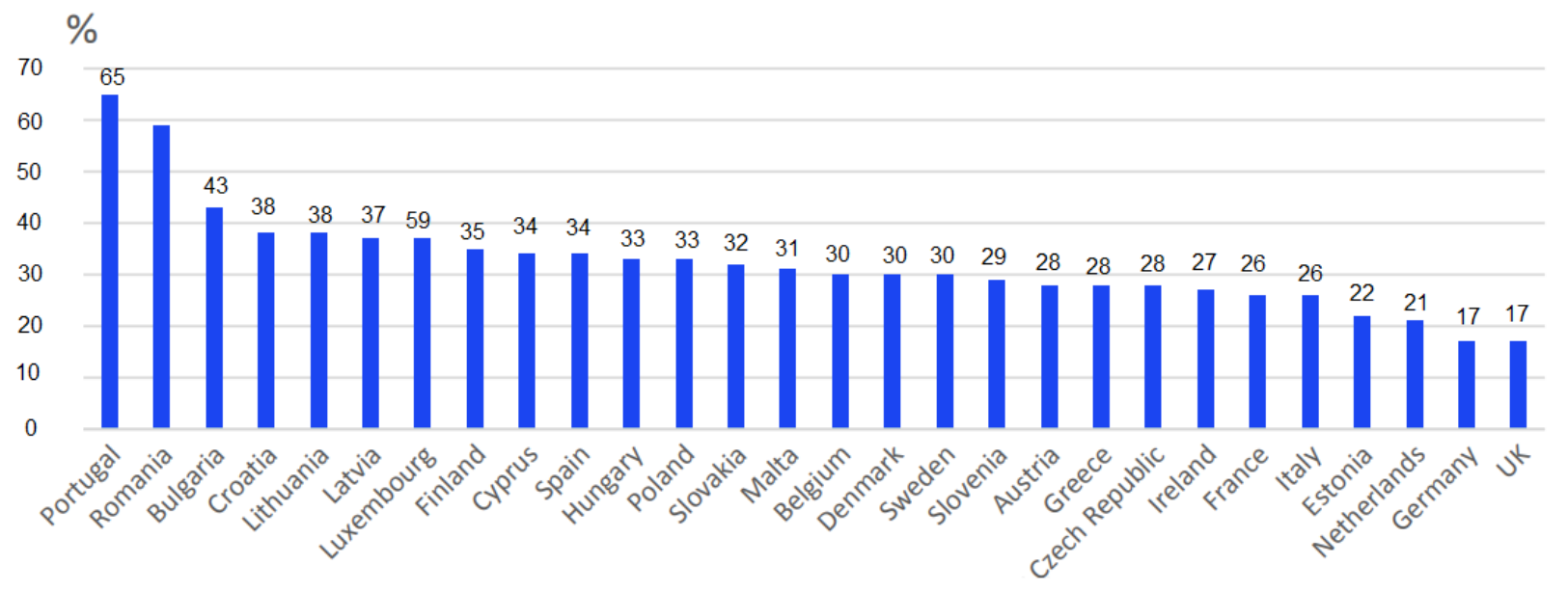

Figure 2: Students' perception on the role of school in becoming an entrepreneur Source: Saraiva, \& Gabriel, 2016

Compared to students from Serbia, some of the EU countries have a more developed approach when it comes to entrepreneurship education, as the students perceive the school's role relevant for becoming an entrepreneur. However, the EU also has its issues regarding entrepreneurship. Government regulations often create barriers. In Serbia, starting capital is one of the main barriers for starting a business (Somer et al., 2018). Students in Serbia portray the necessity for a good idea as the main factor for success. Practical knowledge is also regarded as important. The issues start here, as the SMEs sector is not developed enough in order to provide support for new potential entrepreneurs. The government has difficulties to address the youth in a motivating, engaging, and supporting way.

A conducted research showed that $49 \%$ of students in Serbia are not informed about how to start a business, while $30 \%$ thinks that starting a business in Serbia is not fast and efficient (Privredni forum mladih, 2016). In the same report of the Chamber of Commerce of Serbia it was highlighted that only $15 \%$ of students are informed about the incentive programs that the Serbian government offers for starting a business, while $27 \%$ are totally uninformed and 58\% are partially informed. These issues may severely affect the youth entrepreneurship potential of Serbia.

When it comes to unemployment rates, there is a large difference between member-states of the EU, where Germany has generally overall lower unemployment rates compared to Greece (Potter, Halabisky, Thompson, Blackburn, \& Molenaar, 2014). Further, Greece has a higher ranking for starting a business $\left(37^{\text {th }}\right)$ according to Doing Business in 2018, compared to Germany $\left(113^{\text {th }}\right)$. The US has a slightly better position $\left(49^{\text {th }}\right)$. However, Serbia has a surprisingly high position $\left(32^{\text {nd }}\right)$, mainly due to the ease of acquiring construction permits. It seems that employment and unemployment rates of young people (aged between 15 and 30 years old), are not a reliable metric for determining the macro-entrepreneurship environment of an economy. Or is it? There are other factors as well, such as ease of doing business, achieving sustainability on the market, registering property, getting credit, electricity, the protection of minority investors and paying taxes, trading across borders and other. Further details from the Doing Business Report from 2018 are presented in Table 2.

According to Table 2, it can be seen that Serbia has a moderately adequate entrepreneurial environment. However, even though the ranking for obtaining construction permits is the highest $\left(10^{\text {th }}\right)$ among all the analyzed countries, the ranking regarding taxation is significantly lower (82th), as well as the ranking for enforcing contracts $\left(60^{\text {th }}\right)$. The shaded values in Table 2 depict higher rankings compared to the rankings of Serbia. Based on these rankings, it is evident that one metric is not enough and several metrics should be addressed in order to create a supportive and motivating environment for existing and potential young entrepreneurs. In the next section, the lean startup approach along with I4.0 technologies will be addressed. Additionally, an entrepreneurship model will be developed based on the application of I4.0 technologies. Furthermore, solutions will be 
suggested. These will be based on several existing studies and available data.

Table 2: Rankings between countries (190) regarding several metrics of doing business

\begin{tabular}{|l|c|c|c|c|c|c|c|c|c|}
\hline \multicolumn{2}{|c|}{ Member-states of the European Union (EU) } \\
\hline Country & Serbia & US & Germany & France & Greece & Romania & Hungary & Croatia & Spain \\
\hline $\begin{array}{l}\text { Ease of doing } \\
\text { business }\end{array}$ & 43 & 6 & 20 & 31 & 67 & 45 & 48 & 51 & 28 \\
\hline $\begin{array}{l}\text { Starting a } \\
\text { business }\end{array}$ & 32 & 49 & 113 & 25 & 37 & 64 & 79 & 87 & 86 \\
\hline $\begin{array}{l}\text { Construction } \\
\text { permits }\end{array}$ & 10 & 36 & 24 & 18 & 58 & 150 & 90 & 126 & 123 \\
\hline $\begin{array}{l}\text { Getting } \\
\text { electricity }\end{array}$ & 96 & 49 & 5 & 26 & 76 & 147 & 110 & 75 & 42 \\
\hline $\begin{array}{l}\text { Registering } \\
\text { property }\end{array}$ & 57 & 37 & 77 & 100 & 145 & 45 & 29 & 59 & 53 \\
\hline Getting credit & 55 & 2 & 42 & 90 & 90 & 20 & 29 & 77 & 68 \\
\hline $\begin{array}{l}\text { Protecting } \\
\text { minority } \\
\text { investors }\end{array}$ & 76 & 42 & 62 & 33 & 43 & 27 & 108 & 29 & 24 \\
\hline Paying taxes & 82 & 36 & 41 & 54 & 65 & 42 & 93 & 95 & 34 \\
\hline $\begin{array}{l}\text { Trading across } \\
\text { borders }\end{array}$ & 23 & 36 & 39 & 1 & 29 & 1 & 1 & 1 & 1 \\
\hline $\begin{array}{l}\text { Enforcing } \\
\text { contracts }\end{array}$ & 60 & 16 & 22 & 15 & 131 & 17 & 13 & 23 & 26 \\
\hline $\begin{array}{l}\text { Resolving } \\
\text { insolvency }\end{array}$ & 48 & 3 & 4 & 28 & 57 & 51 & 62 & 60 & 19 \\
\hline
\end{tabular}

Source: World Bank, 2017

\section{ENTREPRENEUSHIP MODEL BASED ON LEAN STARTUPS AND I4.0 TECHNOLOGIES}

\section{Lean startups}

Lean startups can be viewed as tools and techniques for an agile development of business through hypothesizing, experimenting and adjusting business metrics through trial and error in the entrepreneurial process (Ganzarain, Markuerkiaga, \& Gutiérrez, 2014). In the same research it was noted that innovation plays a key role in long-term competitiveness, in increasing employment rates and economic growth. Entrepreneurs should actively focus on repeatable and profitable business actions and only later on to execute the identified business model and to scale it (Blank, 2013). When it comes to youth entrepreneurship, there seems to be an increasing problem where teachers, professors and educators overall, focus on connecting the dots of entrepreneurship theory and practice (Yang, Sun, $\&$ Zhao, 2018). New ventures often struggle with hit-and-miss strategies and untested hypotheses. It is necessary to conduct the "Search" phase of a new venture and after all the hypotheses are tested and all the testing and verification is conducted, then the venture can develop and create a fully complete business model (Sarma, \& Sun, 2017).
Furthermore, in the research of Frederiksen and Brem (2017) it was noted that a lean startup includes five principles. The first principles "Entrepreneurs are everywhere", means that people who innovate, create and sell products and services can be regarded as entrepreneurs, regardless whether they own businesses or not. The second principle "Entrepreneurship is management", refers to the necessary management skills through which innovation can be controlled in high-risk environments and conditions of uncertainty that a startup faces. The third principle, "Validated learning", includes the acquirement of new knowledge through trial and error approaches to product and service development. Fourth, "Buildmeasure-learn", is best explained as a continuous loop, where new knowledge, values, products and services are created and measured. Finally, the fifth principle "Innovation accounting", includes the identification and application of various startup progress metrics. Here, it is necessary to take into consideration the difference between the developed business models and startups, in order to adequately collect information and feedback for further improvements.

The lean startup approach requires entrepreneurs or teams of entrepreneurs to define the internal scales for growth and innovation in order to precisely 
measure changes and to decrease the likelihood of "dead ends" thus effectively decrease unnecessary costs (Breuer, 2013). Evidently, lean startups are based on lowering costs by not pursuing every undefined market segment with untested products or services, as these are cost-demanding. Similarly, there is no need for scaling up business, before there is no tested product or service which will ensure a somewhat stable stream of revenue. In the next section, I4.0 technologies will be addressed.

\section{Industry 4.0 technologies}

The fourth industrial revolution, or Industry 4.0 (also addressed as I4.0 or I4) is characterized with cyber physical systems (CPS) with its main goal to meet the necessary agility in the production process in order to increase overall efficiency and effectiveness of the entire industry (Lu, 2017). Now, there are several groups of technologies which are regarded as Industry 4.0 technologies. These are, but not limited to, autonomous robots, simulations, horizontal and vertical system integration, cyber-security, the industrial Internet of Things, cloud technologies, additive manufacturing, and big data and analytics (Gerbertet et al., 2015). Industry 4.0 can increasingly support lean manufacturing processes, reducing various forms of waste (transport, time, defect products/services etc.) as it applies information and communication systems (Sanders, Elangeswaran, \& Wulfsberg, 2016). Even though I4.0 brings a new paradigm for how the manufacturing sector and overall business world function, there are still concerns when it comes to the integration and application of these technologies. A large number of SMEs are concerned about the financial risks that I4.0 technologies bring (Sommer, 2015). Before this issue is addressed, it is necessary to analyze I4.0 from two main perspectives. The first perspective is the macro perspective that includes the crosslinking of stakeholders, raw materials, production, and the end of product or service exploitation. Basically, it is a cycle that starts from acquiring raw material and other resources until the end-oflife phase of the product. The second perspective is the micro perspective that includes the processed within one "smart" factory, such as inbound logistics, cloud, infrastructure, technology development, human resources, marketing sales, manufacturing, and other (Stock, \& Seliger, 2016).

Now, we are going back to the potential risks of implementing I4.0. These risks are heavily influenced by the type of I4.0 technology, industry, company size, products and services, competitors etc. In the case of youth entrepreneurship it would be counterproductive to implement I4.0 automated manufacturing robots and other automated machines and manufacturing systems. However, new ventures could take advantage of other I4.0 tech, such as cloud technologies. Storing and distributing data, information and connectivity between new enterprises and existing SMEs can positively influence and provide support for new enterprises. Young entrepreneurs should incorporate cloud based services, many of which provide free services with certain limitations. This way, business networks can be developed and data bases shared with useful information that could be used. This approach would be effective in developing countries, and in non-high tech industries. In the next section an entrepreneurship model will be presented.

\section{Entrepreneurship model}

This theoretical model is based on the lean startup approach and I4.0 technologies, more precisely on cloud computing services and distance manufacturing. The model depicts several modules and how these modules are connected. The specific nuances are not given, as every startup differs from one another, thus narrowly specializing is not advised. The model is based on several other models in the domain of entrepreneurial models (Bhave, 1994; Chesbrough, 2002; Chesbrough, 2010; Osterwalder, \& Pigneur, 2010; Ruzzier, Hisrich, \& Antoncic, 2006) - figure 3.

In Figure 3, it can be seen that every module has a circle with a number. These numbers are labels for further detailing the specific module. More details on the modules are given in Table 3. 


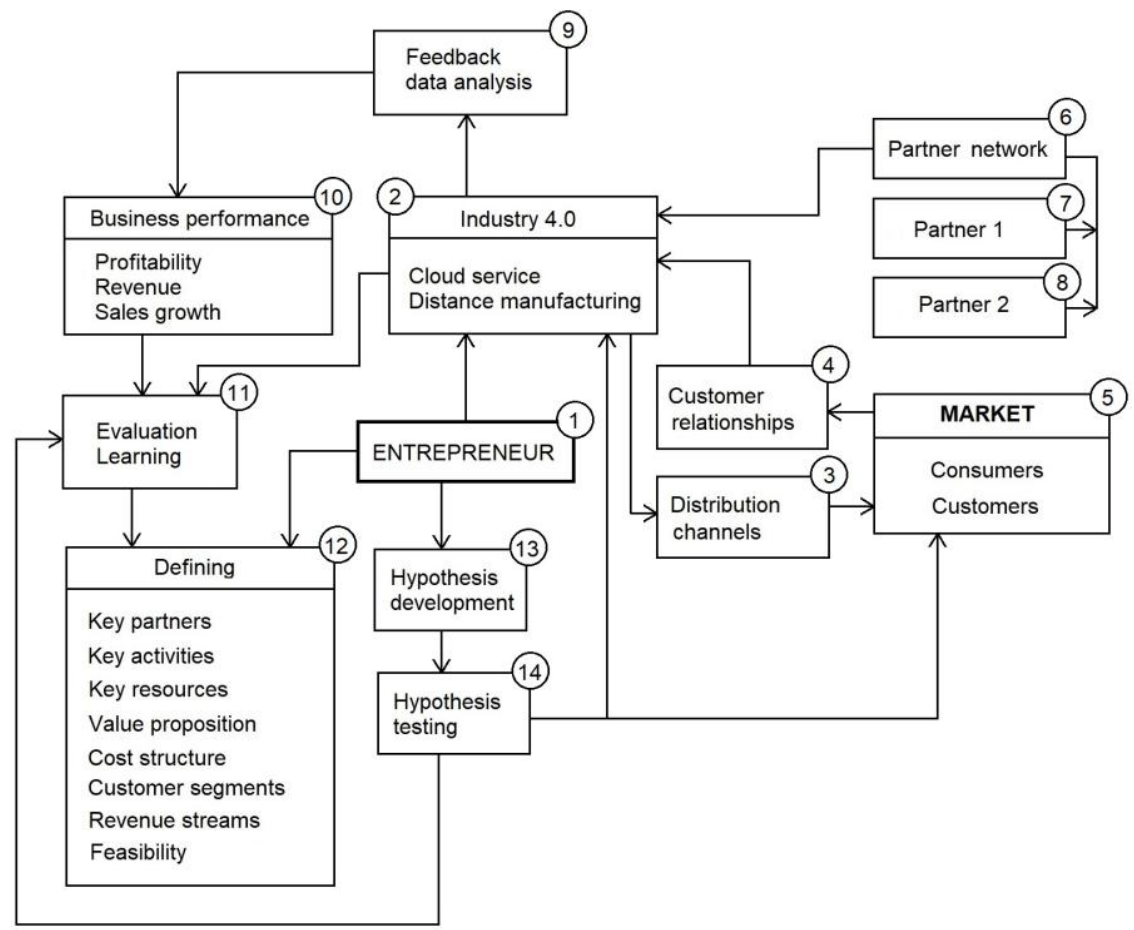

Figure 3: Entrepreneurial with lean startup approach and I4.0 technologies Source: Developed for this research

Table 3: Details about the modules- part 1

\begin{tabular}{|c|l|c|l|}
\hline Label & Details on the module & Label & Details on the module \\
\hline 1 & $\begin{array}{l}\text { The entrepreneur module represents the } \\
\text { individual or group who started the enterprise. }\end{array}$ & 5 & $\begin{array}{l}\text { The Market module represents a specific } \\
\text { market segment that the enterprise targets. The } \\
\text { market includes customers and consumers. } \\
\text { Data collected from the market is collected } \\
\text { through customer relationships and it can be } \\
\text { stored and analyzed within the cloud service. }\end{array}$ \\
\hline 2 & $\begin{array}{l}\text { The Industry 4.0 module includes two tools: } \\
\text { cloud services and distance manufacturing. } \\
\text { Entrepreneurs can develop, store, share and } \\
\text { distribute information through cloud services, } \\
\text { thus reducing waste (time). Feedback from } \\
\text { customers can also be accessed through this } \\
\text { service. Distance manufacturing can be used } \\
\text { in order to effectively delegate manufacturing } \\
\text { needs of the startup. In addition, partnership } \\
\text { can be made, in order to reduce costs and } \\
\text { increase efficiency. }\end{array}$ & 6 & $\begin{array}{l}\text { Partner networks represent an information and } \\
\text { communication system where partners of the } \\
\text { enterprise can connect with existing cloud } \\
\text { services and provide support for the startup. } \\
\text { The partner network can be integrated within } \\
\text { the cloud service }\end{array}$ \\
\hline 3 & $\begin{array}{l}\text { Through distribution channels, products and } \\
\text { services are delivered to customers, and } \\
\text { potential customers (consumers). }\end{array}$ & 7 & $\begin{array}{l}\text { A partner can be another enterprise, startup, } \\
\text { SME, corporation, supplier or any other } \\
\text { individual, group or organization that can } \\
\text { provide support free of charge or through } \\
\text { defined contracts and deals. }\end{array}$ \\
\hline 4 & $\begin{array}{l}\text { Customer relationships play an important role } \\
\text { in the lean startup approach. Crucial feedback } \\
\text { can be collected in order to improve existing } \\
\text { products and services in order to satisfy the } \\
\text { needs and wishes of customers. }\end{array}$ & 8 & $\begin{array}{l}\text { Multiple partners can work together with the } \\
\text { startup. The specific role of these business } \\
\text { partners depends on the needs of the startup or } \\
\text { entrepreneur. }\end{array}$ \\
\hline
\end{tabular}

Source: Developed for this research 
Table 3: Details about the modules- part 2

\begin{tabular}{|c|l|c|l|}
\hline Label & \multicolumn{1}{|c|}{ Details on the module } & Label & \multicolumn{1}{c|}{ Details on the module } \\
\hline 9 & $\begin{array}{l}\text { Feedback and data analysis include the storing } \\
\text { and processing of data collected from } \\
\text { customer feedback, partner feedbacks, and } \\
\text { overall business performance metric data. This } \\
\text { is one of the most important modules of the } \\
\text { lean startup as data obtained here is used for } \\
\text { improvements and innovations. }\end{array}$ & 12 & $\begin{array}{l}\text { After evaluation and data analysis, it is } \\
\text { necessary to define several key metric of the } \\
\text { startup. This is done through cycles, starting } \\
\text { with the launch date of the startup. }\end{array}$ \\
\hline 10 & $\begin{array}{l}\text { This module addresses business performance } \\
\text { metrics that are measured. These include } \\
\text { profitability, sales growth and identifying } \\
\text { revenue streams. It is necessary to } \\
\text { continuously measure these metrics so } \\
\text { adequate and timely improvements can be } \\
\text { conducted to the business strategy. }\end{array}$ & 13 & $\begin{array}{l}\text { The main characteristic of the lean startup is } \\
\text { to develop hypotheses based on various } \\
\text { performance metrics. This way, costs can be } \\
\text { reduced before scaling up business and } \\
\text { necessary adjustments and innovations of } \\
\text { products and services can be detected. }\end{array}$ \\
\hline 11 & $\begin{array}{l}\text { Evaluation of the obtained results from the } \\
\text { data analysis is used to acquire new } \\
\text { knowledge about overall business } \\
\text { performance and startup "health". }\end{array}$ & 14 & $\begin{array}{l}\text { Hypothesis testing includes taking action } \\
\text { based on the proposed hypothesis. This can be } \\
\text { the start of a new cycle where feedback is } \\
\text { collected for a new round of improvements or } \\
\text { innovations. It is not rare for a startup to } \\
\text { dismiss certain ideas after some testing. }\end{array}$ \\
\hline
\end{tabular}

Source: Developed for this research

In the next section potential solutions for the barriers that youth entrepreneurship faces in Serbia are suggested.

\section{DISCUSSION}

\section{Findings}

Youth entrepreneurship faces challenges in Serbia. As mentioned before, it is evident that there are many issues when it comes to developing countries and entrepreneurial activity. Namely, the main issues are financial in nature. Starting capital for startups is hard to obtain. Government financial support is not adequate as the starting costs are often high. Banks are not keen to give out loans for startups but rather for developed businesses (Bobić, 2017). Previous studies that evaluated the importance of entrepreneurship for economic development, noted that entrepreneurship oriented environments have a tremendously positive influence on economic growth (Acs, Estrin, Mickiewicz, \& Szerb, 2018). Furthermore, regulation of credit, business and labor laws have a positive impact on economic growth while the size of government agencies is negatively correlated to entrepreneurial activity (Bosma, Content, Sanders, \& Stam, 2018). In the same research it was noted that intensive nurturing of entrepreneurial culture and rising awareness among students bring positive outcomes when it comes to country-wide entrepreneurial activity.
Further, youth entrepreneurship has an increasingly important role for reducing youth emigration to EU countries. Serbia faces a large set of regulatory and taxation problems, as these create a strong repulsion of the young for any entrepreneurial activity. The lack of motivation among the young in Serbia is due to the lack of starting capital, lack of necessary knowledge, and lack of innovative ideas (Ćoćkalo, Đorđević, Nikolić, Stanisavljev, \& Terek, 2017a; Ćoćkalo, Đorđević, Nikolić, Stanisavljev, \& Terek, 2017b). These issues should be addressed with introducing financial support and taxation regulations as mentioned before.

Now, in the Introduction section of this present paper, two research questions were asked:

1. What are the main challenges of youth entrepreneurship in Serbia and how does it compare to developed countries in the EU and US?

Youth entrepreneurship faces three main issues. These were mentioned before and include the lack of starting capital due to unsupportive government stimulations and bank loan bias towards developed SMEs. Additionally, there is a lack of perspective and necessary entrepreneurial knowledge. In comparison, the youth in the EU and in the US are somewhat in a better financial situation. Taxing is more sufficiently regulated and defined (World 
Bank, 2017). Entrepreneurial behavior is encouraged in the US, as well as in the EU. Serbia suffers a post-communist mentality where the majority of the population prefers government/public jobs compared to owning their own business.

2. What approach can be taken for youth entrepreneurship improvement?

This was answered in the suggestions section of the paper. In sum, regulating taxation events for young entrepreneurs/new startups, introducing non-biased financial support from the government, introduce strict mechanisms to eradicate corruption and exploitation of government funds in the name of entrepreneurship. Current regulations and strategies lack specific and explicit action among policy makers and enforcers. Non-refundable loans should be regulated and controlled. Reducing the overall intensity of malversations in SMEs sector is an imperative for a loyal competition and for the creation of perspective for young entrepreneurs (Bobić, 2017).

These findings have to be addressed with caution, as there is a large set of factors than can affect economic growth and economic development, even if only viewed from an entrepreneurial perspective.

\section{Directions for improvement}

The following actions are suggested as potential solutions for youth entrepreneurship barriers in Serbia:

- Reducing and simplifying the number of laws and by-laws and the frequency of their change over time periods (currently it is every two weeks (Bobić, 2017);

- Reduce the complexity of bureaucratic procedures and the difficulty of acquiring necessary licences;

- Reducing and enforcing existing laws that regulate disloyal competition;

- Regulating the enforcement of contracts and reducing dispute resolution times;

- Regulating the liquidation process and reducing liquidation process times;

- Providing starting capital through government agencies, and promoting them in order to raise awareness among students;

- Introduce entrepreneurship courses to highschools and entrepreneurship introduction presentations at elementary schools;
- Increase focus on youth entrepreneurship in the non-IT sector as well;

- Introduce micro-solutions and actions for local communities, not only country-wide, long-term strategies;

- Reduce taxes for start ups and introduce "norevenue, no-tax policies";

- Introduce new forms of entrepreneurial categories and apply flexible taxation based on profits or revenue;

- Introduce strict fiscal policies in order to reduce the exploitation of new "no-revenue, no-tax" policies;

- Introduce online platforms where SMEs, new entrepreneurs and potential entrepreneurs can develop networks and obtain valuable information;

- Introduce guarantees for banks who give start up loans to new entrepreneurs, not only for developed businesses;

- Expand the systematic financial support for young entrepreneurs;

- Introduce other mechanisms that will ensure that a larger number of young entrepreneurs can acquire essential financial support;

- Develop partnerships with SMEs and arrange paid internships for high-school students, undergraduate and graduate students.

These suggestions can be further developed and to address specific communities, high-schools or universities. However, governmental policies and regulatory policies should be modified in accordance with the main issues which are fiscal policies, taxation and financial support. In the next section, conclusions are drawn.

\section{CONCLUSION}

The investigation of entrepreneurship influence on economic development showed that there is a positive impact of entrepreneurship activity on economic prosperity. The insights gained in this research can be assistance to future research in this domain. Certainly, global and national reports on entrepreneurship and economic development are an important asset when conducting this kind of research. However, data for these reports can often over generalize the actual situation, which may lead to countries portrayed as undervalued or overvalued from the aspect of entrepreneurial ecosystems. This present study adds to the growing body of literature in this domain and indicates that self-employment is the key for reducing 
unemployment rates and to activate resources that will bring value for the people and the economy. The theoretical entrepreneurship model presented in this paper includes the application of I4.0 technologies and the lean startup approach. I4.0 technologies, more precisely cloud services and distance manufacturing, in this case can highly reduce production costs and market research costs. Through hypothesis development and testing, young entrepreneurs can reduce costs before scaling their business.

The main limitation of this study is that it couldn't compare Serbia, EU and the US through global reports, as Serbia was not included in those reports for the past eight years. This is due to the lack of regulatory institutions that would conduct the necessary research in order to satisfy the requirements of the report. Therefore, the comparison of these economies was conducted with the data available from the Doing Business 2018 report. Future research is recommended in this domain. The analyzed metrics and suggested solutions would be interesting to analyze and apply in practice. For future studies it is suggested to address several governmental regulations and taxation options and compare them among several countries. In addition, other studies can be investigated in order to further determine the causational relationship between entrepreneurship and economic development.

\section{ACKNOWLEDGEMENT}

This paper has been supported by the Provincial Secretariat for Higher Education and Scientific Research of the Autonomous Province of Vojvodina, number: 142-451-2461/2018-03.

\section{REFERENCES}

Acs, Z., Estrin, S., Mickiewicz, T. M., \& Szerb, L. (2018). Entrepreneurship, Institutional Economics and Economic Growth: A Systems Perspective. Paper presented at the Academy of Management Proceedings.

Acs, Z., \& Storey, D. (2004). Introduction: Entrepreneurship and economic development. Regional studies, 38, 871-877. doi: 10.1080/0034340042000280901

Acs, Z. J., Desai, S., \& Hessels, J. (2008). Entrepreneurship, economic development and institutions. Small Business Economics, 31(3), 219 234. doi: 10.1007/s11187-008-9135-9

Aničić, J., Aničić, D., \& Vasić, N. (2017). Entrepreneurship development and financial performances in SMEs sector in Serbia. Ekonomika, 63(4), 29-39. doi: 10.5937/ekonomika1704029A

Audretsch, D. B., Bönte, W., \& Keilbach, M. (2008). Entrepreneurship capital and its impact on knowledge diffusion and economic performance. Journal of Business Venturing, 23(6), 687-698. doi: 10.1016/j.jbusvent.2008.01.006

Bhave, M. P. (1994). A process model of entrepreneurial venture creation. Journal of Business Venturing, 9(3), 223-242. doi: 10.1016/08839026(94)90031-0

Blank, S. (2013). The four steps to the epiphany: successful strategies for product that win. Pescadero: K \& S Ranch.

Bobić, D. (2017). Preduzetništvo maldih u SrbijiMapiranje prepreka za preduzetništvo mladih (eng. Mapping the barriers for youth entrepreneurship in Serbia). Beograd: Deutsche Gessellschaft fur Internationale Zusamenarbeit (GIZ) Gmbh.

Boettke, P. J., \& Coyne, C. J. (2015). Entrepreneurship and development: Cause or consequence? Austrian Economics and Entrepreneurial Studies (pp. 67-87): Emerald Group Publishing Limited.

Bøllingtoft, A., \& Ulhøi, J. P. (2005). The networked business incubator-leveraging entrepreneurial agency? Journal of Business Venturing, 20(2), 265290. doi: 10.1016/j.jbusvent.2003.12.005

Bortolini, R. F., Nogueira Cortimiglia, M., Danilevicz, A. d. M. F., \& Ghezzi, A. (2018). Lean Startup: a comprehensive historical review. Management Decision. doi: 10.1108/md-07-2017-0663

Bosma, N., Sanders, M., \& Stam, E. (2018). Institutions, entrepreneurship, and economic growth in Europe. Small Business Economics, 51(2), 1-17. doi: 10.1007/s11187-018-0012-X

Breuer, H. (2013). Lean venturing: Learning to create new business through exploration, elaboration, evaluation, experimentation, and evolution. International Journal of Innovation Management, 17(3), 1340013. doi: 10.1142/S1363919613400136

Carree, M. A., \& Thurik, A. R. (2010). The impact of entrepreneurship on economic growth Handbook of Entrepreneurship Research (pp. 557-594). New York: Springer.

Chesbrough, H. (2010). Business model innovation: opportunities and barriers. Long Range Planning, 43(2-3), 354-363. doi: 10.1016/j.lrp.2009.07.010

Chesbrough, H., \& Rosenbloom, R. S. (2002). The role of the business model in capturing value from innovation: evidence from Xerox Corporation's technology spin- off companies. Industrial and Corporate Change, 11(3), 529-555. doi: 10.1093/icc/11.3.529

Ćoćkalo, D., Đorđević, D., Nikolić, M., Stanisavljev, S., \& Terek, E. (2017a). Analysis of possibilities for improving entrepreneurial behaviour of young people: Research results in Central Banat district. Journal of Engineering Management and Competitiveness (JEMC), 7(2), 97-108. 
Ćoćkalo, D., Đorđević, D., Nikolić, M., Stanisavljev, S., \& Terek, E. (2017b). Development of the entrepreneurial behavior among young peopleResearch results from the Banat region. Paper presented at the The Seventh International Symposium "Engineering Management and Competitiveness" - EMC 2017, Zrenjanin.

Djordjevic, D., Cockalo, D., Sajfert, Z., Bogetic, S., \& Klarin, M. (2011). Competitive abilities and students entrepreneurial behaviour: The research results from Serbia. African Journal of Business Management, 5(26), 10878-10884. doi: 10.5897/AJBM11.385

Frederiksen, D. L., \& Brem, A. (2017). How do entrepreneurs think they create value? A scientific reflection of Eric Ries' Lean Startup approach. International Entrepreneurship and Management Journal, 13(1), 169-189. doi: 10.1007/s11365-0160411-x

Ganzarain, J., Markuerkiaga, L., \& Gutiérrez, A. (2014). Lean startup as a tool for fostering academic \& industry collaborative entrepreneurship. Paper presented at the Inted2014: 8th International Technology, Education and Development Conference, Valencia, Spain.

Gerbert, P., Rüßmann, M., Lorenz, M., Waldner, M., Justus, J., Engel, P., \& Harnisch, M. (2015). Industry 4.0: The future of productivity and growth in manufacturing industries. Boston Consulting Group, 9, 1-14.

Global Entrepreneurship Monitor - GEM (2018). Global report 2017/18. London, UK: Global Entrepreneurship Research Association (GERA).

Karanassios, N., Pazarskis, M., Mitsopoulos, K., \& Christodoulou, P. (2006). EU strategies to encourage youth entrepreneurship: Evidence from higher education in Greece. Industry and Higher

Education, 20(1), 43-50. doi: $10.5367 / 000000006776150747$

Lee, S. Y., Florida, R., \& Acs, Z. (2004). Creativity and entrepreneurship: A regional analysis of new firm formation. Regional Studies, 38(8), 879-891. doi: $10.1080 / 0034340042000280910$

Lu, Y. (2017). Industry 4.0: A survey on technologies, applications and open research issues. Journal of Industrial Information Integration, 6, 1-10. doi: 10.1016/j.jii.2017.04.005

Minniti, M., \& Lévesque, M. (2008). Recent developments in the economics of entrepreneurship. Journal of Business Venturing, 23(6), 603-612. doi: 10.1016/j.jbusvent.2008.01.001

Naudé, W. (2010). Entrepreneurship, developing countries, and development economics: new approaches and insights. Small Business Economics, 34(1), 1. doi: 10.1007/s11187-009-9198-2

Osterwalder, A., \& Pigneur, Y. (2010). Business model generation: a handbook for visionaries, game changers, and challengers: John Wiley \& Sons.

Otović, S., Demirović, D., Košić, K., \& Vujko, A. (2017). Fostering entrepreneurship at high schools: a case of rural areas in Vojvodina (Serbia). Economics of Agriculture, 64(4), 1523-1535. doi:

10.5937/ekoPolj17045230

Potter, J., Halabisky, D., Thompson, S., Blackburn, R., \& Molenaar, K. (2014). Supporting Youth in Entrepreneurship. Brussels, Belgium: Centre for Entrepreneurship, SMEs and Local Development and the European Commission.

Privredni forum mladih (2016). Analiza rezultata istraživanja o potrebama potencijalnih i postojećih mladih preduzetnika u Republici Srbiji (eng. Analysis of research results regarding the needs of potential and existing young entrepreneurs in the Republic of Serbia. Belgrade, Serbia: Pivredna komora Srbije

Rae, D., \& Melton, D. E. (2017). Developing an entrepreneurial mindset in US engineering education: an international view of the KEEN project. The Journal of Engineering Entrepreneurship, 7(3).

Rodrigues, R. G., Raposo, M., Ferreira, J., \& Do Paco, A. (2009). Entrepreneurship education and the propensity for business creation: testing a structural model. International Journal of Entrepreneurship and Small Business, 9(1), 58-73. doi:

10.1504/ijesb.2010.029506

Ruzzier, M., Hisrich, R. D., \& Antoncic, B. (2006).

SME internationalization research: past, present, and future. Journal of Small Business and Enterprise Development, 13(4), 476-497. doi: 10.1108/14626000610705705

Sanders, A., Elangeswaran, C., \& Wulfsberg, J. (2016). Industry 4.0 implies lean manufacturing: research activities in industry 4.0 function as enablers for lean manufacturing. Journal of Industrial Engineering and Management, 9(3), 811-833. doi: 10.3926/jiem. 1940

Saraiva, H. I., \& Gabriel, V. (2016). Entrepreneurship and education in the European Union: Student's perception on the subject. The International Journal of Management Science and Information Technology (IJMSIT)(22), 40-58.

Sarma, S., \& Sun, S. L. (2017). The genesis of fabless business model: Institutional entrepreneurs in an adaptive ecosystem. Asia Pacific Journal of Management, 34(3), 587-617. doi: 10.1007/s10490016-9488-6

Shinnar, R., Pruett, M., \& Toney, B. (2009). Entrepreneurship education: Attitudes across campus. Journal of Education for Business, 84(3), 151-159. doi: 10.3200/joeb.84.3.151-159

Sobel, R. S., Clark, J., \& Lee, D. R. (2007). Freedom, barriers to entry, entrepreneurship, and economic progress. The Review of Austrian Economics, 20(4), 221-236. doi: 10.1007/s11138-007-0023-3

Somer, A., Arsić, K., Govedarica, N., Nikolić, K., Pavković, Subotić, L., \& Todorović. (2018). Stavovi studenata Univerziteta u Beogradu o preduzetništvu mladih u Republici Srbiji (eng. Attitudes of students from the University of Belgrade about youth entrepreneurship in the Republic of Serbia). 
Beograd, Srbija: Centar za Međunarodnu i Javnu Politiku (eng. Center for International and Public Politics).

Sommer, L. (2015). Industrial revolution-industry 4.0: Are German manufacturing SMEs the first victims of this revolution? Journal of Industrial Engineering and Management, 8(5), 1512-1532. doi: $10.3926 /$ jiem. 1470

Stock, T., \& Seliger, G. (2016). Opportunities of sustainable manufacturing in industry 4.0. Procedia Cirp, 40, 536-541. doi: 10.1016/j.procir.2016.01.129

Van Stel, A., Carree, M., \& Thurik, R. (2005). The effect of entrepreneurial activity on national economic growth. Small Business Economics, 24(3), 311-321. doi: 10.1007/s11187-005-1996-6

Wach, K. (2014). Europeanisation of Entrepreneurship Education in Europe-Looking Back and Looking Forward. Horyzonty Wychowania, 13(26), 11-31.
Wiklund, J., \& Shepherd, D. (2003). Knowledge- based resources, entrepreneurial orientation, and the performance of small and medium- sized businesses. Strategic Management Journal, 24(13), 1307-1314. doi: 10.1002/smj.360

Wilson, K. E. (2008). Chapter 5: Entrepreneurship Education in Europe. Entrepreneurship and higher education, OECD. https://srn.com/abstract=1392369:

World Bank (2017). Doing Business 2018: Reforming to Create Jobs. from The World Bank Group

Yang, X., Sun, S. L., \& Zhao, X. (2018). Search and execution: examining the entrepreneurial cognitions behind the lean startup model. Small Business Economics, 1-13. doi: 10.1007/s11187-017-9978-Z

\title{
LEAN STARTUP-OVI ZASNOVANI NA TEHNOLOGIJAMA INDUSTRIJE 4.0: PREVAZILAŽENJE IZAZOVA PREDUZETNIŠTVA MLADIH U SRBIJI
}

\begin{abstract}
Preduzetništvo mladih je važno zbog smanjenja stope nezaposlenosti u ovoj populaciji i doprinosa ekonomskom rastu. Glavna ideja ovog istraživanja je određivanje barijera i izazova sa kojima se susreću mladi preduzetnici u Srbiji. Ovaj rad analizira literaturu u ovom domenu i upoređuje stanje preduzetništva kod mladih kao i preduzetništva uopšte u Srbiji, EU i Americi. U nastavku, razvijen je teorijski model koji uključuje primenu „Indsutrija 4.0“ tehnologije i "lean startup" pristup. Rezultati istraživanja indikuju da su neadekvatno regulsianje poreza i nedostatak finansijske podrške za nove startup-ove glavne barijere sa kojima se mladi susreću u Srbiji. Dodatno, nedostatak adekvatnog preduzetničkog obrazoavanja stvara poteškoće i demotiviše potencijalne mlade preduzetnike. Samim tim, potrebno je uvesti ili modifikovati postojeće regulisanje poreza i uvesti efektivnu finansijsku prodšku novim preduzećima i preduzetnicima.
\end{abstract}

Ključne reči: Preduzetništvo kod mladih, Industrija 4.0, Lean startup-ovi, Srbija. 